ALEKSANDAR ŽIVOTIĆ, naučni saradnik

Institut za noviju istoriju Srbije

Beograd, Trg Nikole Pašića 11
UDK 94(497.1)"1941"

355.48(497.1)"1941"

$355.318(497.1) " 1941 "$

\title{
ČETNIČKE JEDINICE VOJSKE KRALJEVINE JUGOSLAVIJE U APRILSKOM RATU
}

\begin{abstract}
APSTRAKT: Rad sadrži prikaz dejstva četničkih jedinica Vojske Kraljevine Jugoslavije tokom Aprilskog rata. Pisan je na osnovu dostupne arhivske grade Vojnog arhiva i relevantne istoriografske literature.
\end{abstract}

Ključne reči: Jugoslavija, četnici, Aprilski rat, gerila, Drugi svetski rat

Jugoslovenska vojna doktrina između dva svetska rata temeljila se na iskustvima iz Balkanskih ratova i Prvog svetskog rata. Sa takvim doktrinarnim shvatanjima jugoslovensko vojno rukovodstvo dočekalo je početak Drugog svetskog rata. Krajem tridesetih godina 20. veka vojno-politička situacija u Evropi i svetu se naglo pogoršavala. Španski građanski rat (1936-1939), zauzimanje Čehoslovačke i anšlus Austrije od strane Nemačke 1938, a potom i pad Poljske i poraz združenih francusko-britanskih snaga u Francuskoj 1940, nametali su drukčiji pogled na rat. Naime, u Španskom građanskom ratu i početnim fazama Drugog svetskog rata promovisana su nova načela ratovanja koja su se zasnivala na širokoj primeni oklopno-mehanizovanih i motorizovanih jedinica uz opsežnu i snažnu podršku vazduhoplovnih snaga.

Anšlus Austrije od strane Nemačke 1938. godine primorao je jugoslovenski generalštab na prvu ozbiljniju reviziju ratnih planova. Posledica novog obrta na globalnom planu krajem 1939. bila je stvaranje potpuno novog ratnog plana. Elaborat novog ratnog plana usvojen je početkom 1940. godine i dobio je oznaku „S“. U prvoj fazi rata plan je predviđao odbranu graničnih frontova, a zatim postepeno povlačenje prema planinskim predelima u unutrašnjost zemlje iza linije Una-Sava-Dunav. Elaborat ovog ratnog plana nije sačuvan ali se na osnovu izjava armijskog generala Dušana Simovića, tadašnjeg načelnika Glavnog generalštaba i generalštabnog pukovnika Branka Popovića, u vreme izrade plana na dužnosti u Operativnom odeljenju Glavnog generalštaba, datim posle Drugog svetskog rata, vidi da je ovaj ratni plan predviđao upotrebu gerilskih jedinica. $\mathrm{Pu}$ kovnik Popović navodi da je ratni plan „S“ predviđao „operacije u obliku dubokog manevra u naslonu na delom utvrđene granične frontove, a potom na više jakih rečnih i planinskih linija sa težnjom da se vojska kao celina ne izloži cepanju 
i uništenju po delovima. Pri ovome je uzeta u razmatranje i gerila na teritoriji sa koje se budu povukle naše trupe. " ${ }^{1}$ Sličnu tvrdnju iznosi i general Dušan Simović. On ističe da je ratni plan „S“ predviđao „rad gerilskih odreda u pozadini neprijateljske vojske u vezi sa graničarima, stanovništvom i, eventualno, žandarmerijom sa naslonom na vojna slagališta i ustanove koje vojska bude napustila.“2

U januaru 1940. general Simović je smenjen, a na dužnost načelnika Glavnog generalštaba postavljen je armijski general Petar Kosić pod čijim rukovodstvom je sačinjen novi ratni plan „R-40”. Ovaj ratni plan je donet usled promena na vojno-političkom planu izazvanih italijanskom okupacijom Albanije, napadom na Grčku i približavanjem Bugarske silama Osovine. I ovaj ratni plan je predviđao upotrebu specijalnih gerilskih jedinica u neprijateljskoj pozadini. Početkom 1940 . godine usvojen je ratni plan „R-41“ koji je u pogledu upotrebe jedinica specijalizovanih za gerilske operacije sadržavao istovetna rešenja kao prethodni ratni planovi.

Pošto jugoslovenski Generalštab nije raspolagao jačim oklopno-mehanizovanim i motorizovanim jedinicama bio je prinuđen da snažnim neprijateljskim oklopno-mehanizovanim i motorizovanim jedinicama parira, između ostalog, i specijalnim gerilskim jedinicama koje su, prema ovim zamislima, trebale da budu i nosioci kompletnih specijalnih dejstava.

Rukovodeći se navedenim razlozima ministar vojske i mornarice, armijski general Milan Nedić, doneo je 8. maja doneo uredbu o formiranju Četničke komande. ${ }^{3} \mathrm{Na}$ ovaj način pristupilo se praktičnom ostvarivanju zamisli iznetih u ratnom planu „S“. Na dužnost komandanta Četničke komande postavljen je brigadni general Mihailo S. Mihailović, dotadašnji komandant Škole za rezervne pešadijske oficire u Sarajevu. ${ }^{4}$ Inače, general Mihailović je bio iskusan gerilac: učestvovao je u gerilskim akcijama u Makedoniji i južnoj Srbiji tokom 1911. i 1912. i na Solunskom frontu 1916-1918. ${ }^{5}$ Za načelnika Štaba Četničke komande posta-

\footnotetext{
${ }^{1}$ Arhiv Vojnoistorijskog instituta (dalje: AVII), popisnik 17 (dalje: P 17), kutija (dalje: K) 5, registarski broj (dalje: reg. br.) 8/1.

${ }^{2}$ AVII, P 17 , K 5 , reg. br. $18 / 1$.

${ }^{3}$ Službeni vojni list (dalje: SVL), br. 17/1940, uredba Đ. br. 12215 / 1940, 1-3.

${ }^{4}$ AVII, P 17, K 11 , reg . br. 5/2.

${ }^{5}$ Divizijski general Mihailo S. Mihailović je rođen 13. januara 1889. u Užičkoj Požegi. Osnovnu školu i gimnaziju je završio u Valjevu. Po završetku Vojne akademije 1908. unapređen je u čin potporučnika. Službovao je u V i VII pešadijskom puku. Bio je komita u Makedoniji 1911. i 1912. Na početku Prvog svetskog rata borio se kao komandir čete u IV pešadijskom puku. Na Solunskom frontu se borio u sastavu Dobrovoljačkog odreda potpukovnika Vojina Popovića - Vojvode Vuka. Posle rata je bio komandant bataljona u IV, XXXV i XLI pešadijskom puku. Godine 1924. završio je Višu školu Vojne akademije, a potom je bio pomoćnik komandanta XXIII i komandant XXIV pešadijskog puka. U periodu 1927-1930. bio je veliki župan Bregalničke oblasti. Kao brigadni general bio je komandant pešadije Dunavske i Bosanske divizijske oblasti. Od 1938. do 1940. nalazio se na dužnosti komandanta Š́kole za rezervne pešadijske oficire u Sarajevu. Komandant Četničke komande postao je 1940. godine i na toj dužnosti je ostao do kapitulacije Vojske Kraljevine Jugoslavije 18. aprila 1941, kada je zarobljen. Iz zarobljeništva se vratio 1945. Umro je u Beogradu 23. januara 1970.
} 
vljen je generalštabni major Dušan Anđelković. Na zahtev potpredsednika vlade Vlatka Mačeka i njegove Hrvatske seljačke stranke, Četničkoj komandi je uredbom ministra vojske i mornarice od 10. jula 1940. promenjen naziv u Jurišna komanda. ${ }^{6}$ Naziv „Četnička“, po njihovom mišljenju, asocirao je samo na jedan narod i takvim nazivom su izražavane navodne velikosrpske aspiracije, što su smatrali uvredom hrvatskog naroda. Tek je 1. aprila 1941, neposredno pred početak rata, naređenjem ministra vojske i mornarice Jurišnoj komandi vraćen stari, mnogo prikladniji i tradicionalno ukorenjen naziv Četnička komanda. ${ }^{7}$

Jurišna (četnička) komanda je trebalo da bude nosilac gerilskog načina ratovanja jugoslovenske vojske u slučaju da čitava oružana sila pređe u gerilu. Njene jedinice bi tada bile organizaciona, kadrovska i nastavna baza za formiranje novih jedinica slične namene i preformiranje postojećih jedinica kopnene vojske radi adaptiranja na nov način borbenih dejstava. Sem toga, jurišne (četničke) jedinice trebalo je da podnesu celokupan teret specijalnih dejstava u neprijateljskoj pozadini. Taj aspekt upotrebe ovih jedinica obuhvatao je širok dijapazon specijalnih dejstava: od izvođenja diverzantskih akcija do organizovanja obaveštajne službe. Smatralo se da se ovi zadaci mogu uspešno izvršiti samo oslanjanjem na lokalno stanovništvo. Prema potrebi, ove jedinice su mogle biti angažovane i u obezbeđenju komandi strategijskog nivoa i visokih vojnih starešina, kao i za obavljanje zadataka kontraobaveštajne prirode. Bile su zadužene za hvatanje neprijateljskih špijuna i borbu protiv ubačenih diverzantskih grupa i padobranskih desanta.

Četnička komanda se od osnivanja nalazila u Novom Sadu, u Petrovaradinskoj tvrđavi, da bi naredbom ministra vojske i mornarice od 1. aprila 1941, neposredno pred početak Drugog svetskog rata, bila premeštena u Kraljevo. ${ }^{8} \mathrm{Na}$ čelu komande nalazio se komandant koji je imao prava, obaveze i položaj komandanta divizijske oblasti i bio potčinjen ministru vojske i mornarice. Samo je u nastavnom smislu ova komanda bila potčinjena Vrhovnom inspektoru vojne sile. Ovoj komandi su bile potčinjene, neposredno, u komandnom i nastavnom smislu sve četničke jedinice.

Četničkoj komandi je potčinjeno šest četničkih bataljona. ${ }^{9} \mathrm{Na}$ teritoriji svake armijske oblasti je bio dislociran po jedan četnički bataljon. Prvi četnički bataljon je bio dislociran u Novom Sadu, drugi u Sarajevu, treći u Skoplju, četvrti u Karlovcu, peti u Nišu, a šesti u Mostaru. Formiranje Sedmog četničkog bataljona započelo je 1. aprila 1941. u Kraljevu, ali do okončanja kratkotrajnog Aprilskog rata poslovi oko formiranja ovog bataljona nisu završeni. ${ }^{10}$

\footnotetext{
${ }^{6}$ SVL, br. 27/1940, uredba br. 20731/1940, 4-6.

${ }^{7}$ AVII, P $17, \mathrm{~K} 1$, reg. br. 28 / 5.

${ }^{8}$ Isto.

${ }^{9}$ Svaki četnički bataljon su sačinjavali štab bataljona, štabni vod, vod za vezu i dve do tri čete. Prvi i Treći četnički bataljon su imali po tri čete, dok su svi ostali četnički bataljoni imali po

${ }^{10}$ AVII, P 17, K 11 a, reg. br. 3/6-4.
} dve čete. 
Pošto se spoljnopolitička situacija krajem 1940. i početkom 1941. naglo zaoštravala Jurišna (Četnička) komanda je, prema nalozima Ministarstva vojske i mornarice, intenzivirala obučavanje i opremanje potčinjenih jedinica. Posle državnog prevrata od 27. marta 1941. bilo je jasno da je rat sa silama Osovine neizbežan. Zbog toga je i naređeno upućivanje vojnika u jurišne (četničke) jedinice ranije nego u druge jedinice kako bi se u ratu raspolagalo sa više ljudi obučenih za gerilske i diverzantske akcije budući da postojeći kadar, iako dobro obučen, odlično motivisan i solidno opremljen, nije mogao da, zbog malobrojnosti, odgovori svim zadacima koje bi u ratu pred njega postavila pretpostavljena komanda. ${ }^{11}$ Istovremeno je primećeno da se nemački obaveštajci posebno interesuju za raspored, sastav, namenu i opremljenost jurišnih (četničkih) jedinica. ${ }^{12}$ Ministarstvo vojske i mornarice je već 1. aprila 1941. naredilo da se Jurišnoj komandi vrati stari naziv Četnička komanda. Istim naređenjem ovoj komandi je naloženo da se iz Novog Sada preseli u okolinu Kraljeva, kao i da otpočne formiranje Sedmog četničkog bataljona od trećih četa Prvog četničkog bataljona iz Novog Sada i Trećeg četničkog bataljona iz Skoplja. Radi formiranja krupnije formacije ovih jedinica, kojom bi Vrhovna komanda mogla da brzo i energično interveniše na ugroženim pravcima, naređeno je Petom četničkom bataljonu da se iz Niša premesti u Kraljevo gde bi sa novoformiranim Sedmim četničkim bataljonom činio jezgro četničkih jedinica. ${ }^{13}$ Već sutradan Ministarstvo vojske i mornarice dalo je uputstvo komandantu Četničke komande da se u četničke jedinice mogu primati svi oni koji se budu dobrovoljno prijavili Četničkoj komandi za službu u ovim jedinicama, a koji ispunjavaju potrebne uslove i slovenskog su porekla (sem Bugara). ${ }^{14}$ Pošto je bilo predviđeno da ove jedinice uđu u rat sa svojom mirnodopskom formacijom, one nisu imale mobilizaciju pa im je za prelazak sa mirnodopskog na ratni režim rada trebalo svega nekoliko sati.

Podaci o aktivnostima četničkih jedinica u kratkotrajnom Aprilskom ratu od 6. do 18. aprila 1941. vrlo su oskudni. Na osnovu podataka iz raspoloživih izvora samo fragmentarno se može rekonstruisati tok borbenih dejstava svakog četničkog bataljona pojedinačno, pošto nema podataka da su četničke jedinice u borbi angažovane u grupacijama većim od jednog četničkog bataljona.

Štab Četničke komande se prva tri dana rata, 6, 7 i 8. aprila, nalazio u selu Samaila, blizu Kraljeva. Aktivnosti Štaba Četničke komande su bile usmerene na pripremanje logora za prihvat četničkih jedinica kojima je bilo naređeno da se

${ }^{11}$ AVII, P 17, K 11 a, reg . br. 1/3-1.

${ }^{12}$ AVII, P 17, K 11 a, reg. br. 12/3. - Ovoj tvrdnji ide u prilog činjenica da mnogi dokumenti iz Arhiva Ministarstva vojske i mornarice i Glavnog generalštaba koji se tiču Jurišne (četničke) komande i njenih jedinica koji se danas čuvaju u Arhivu Vojnoistorijskog instituta Vojske Jugoslavije u Beogradu, a koje su Nemci zarobili u Sarajevu 18. aprila 1941, sadrže regeste na nemačkom jeziku nastale u Beču 1943. i 1944. godine. Taj podatak svedoči o tome da su ovi dokumenti, za razliku od najvećeg broja drugih dokumenata, bili predmet posebnog nemačkog interesovanja što se može dovesti i u vezu sa događajima na tlu Jugoslavije koji su se desili posle aprilskog sloma Kraljevine Jugoslavije.

${ }_{13}^{13}$ AVII, P $17, \mathrm{~K} 1$, reg. br. $28 / 5$.

${ }^{14}$ AVII, P 17, K 11a, reg. br. 12/3-1. 
premeste u okolinu Kraljeva i izviđanje neposredne okoline logora. Logor je pripreman za odbranu od eventualnih vazdušnih napada: postavljani su protivavionski mitraljezi i kopani zakloni. Po naređenju Štaba Vrhovne komande, Štab Četničke komande je 8. aprila uputio jednu četu novoformiranog Sedmog četničkog bataljona u Kosovsku Mitrovicu na raspolaganje Štabu Treće armije. Stab Četničke komande se prvo prebacio u Užičku Požegu 10. aprila, a potom se 13. aprila prebacio u Rogaticu. Štab se preko Goražda i Foče prebacio 14. aprila u Kalinovik, odakle se 16. aprila povukao u Sarajevo i u tom gradu se 18. aprila predao Nemcima. Zajedno sa Štabom predali su se i ostaci Drugog i Sedmog četničkog bataljona. ${ }^{15}$ Usled loše organizovanog sistema veza koji je često bio u prekidu, ali i decentralizovanog sistema komandovanja jer su neke četničke jedinice privremeno potčinjene drugim komandama, sam Štab Četničke komande nije ispoljio više uticaja na planiranje i izvođenje borbenih dejstava četničkih jedinica tokom Aprilskog rata.

Prvi četnički bataljon se nalazio uz Štab Prve armije sve do 11. aprila kad $\mathrm{mu}$ je naređeno da zbog udara nemačkog 46. korpusa u bok jedinica Prve armije organizuje odbranu prelaza preko reke Save u rejonu Rače. Sledećeg dana ovaj bataljon se povukao do Bijeljine gde je dobio naređenje da organizuje odbranu bijeljinskog aerodroma. Tog 12. aprila Nemci su izveli padobranski desant na ovaj aerodrom na kome su se nalazili preostali avioni 6 . lovačkog i 1 . bombarderskog puka, 11. samostalne izviđačke grupe i 1. i 2. grupe armijske avijacije. ${ }^{16} \mathrm{U}$ žestokoj borbi sa nemačkim padobrancima Prvi četnički bataljon je pretrpeo velike gubitke. Taj bataljon je odolevao nemačkim napadima sve dok Nemci nisu u borbu uveli tenkove, kojima bataljon nije mogao efikasno da se suprotstavi pošto nije raspolagao protivoklopnim sredstvima. Istovremeno, njega su napale i ustaške snage iz pozadine. Izbegavajući zarobljavanje komandant Prvog četničkog bataljona major Miodrag Palošević ${ }^{17}$ i oficiri i podoficiri tog bataljona: kapetan Milenko Reljić, poručnik Borivoje Ilić, potporučnik Pavle Mešković i narednik Gojko Ajvaz sa četvoricom vojnika iz istog bataljona, pridruživši se ostatku Brzog odreda pukovnika Dragoljuba Mihailovića početkom maja 1941. u selu Zaovine na obroncima Zlatibora, stigli su sredinom istog meseca na Ravnu Goru. ${ }^{18}$

${ }^{15}$ Nusret Šehić, Četnici kao nosioci gerilskog oblika ratovanja u planovima najviših vojnih vlasti predratne Jugoslavije, Godišnjak društava istoričara Bosne i Hercegovine, godina XVIII, 127.

${ }^{16}$ Velimir Terzić, Slom Kraljevine Jugoslavije 1941. godine, II tom, 432.

${ }^{17}$ Major Miodrag Palošević je rođen u Beogradu 1901. Kao dečak bio je dobrovoljni bolničar u Balkanskim i Prvom svetskom ratu. Završio je XLVIII klasu Niže škole Vojne akademije 1922. Bio je komandant Prvog jurišnog (četničkog) bataljona od njegovog formiranja do kapitulacije Vojske Kraljevine Jugoslavije. Odbio je da se preda i sa grupom oficira, podoficira i vojnika svog bataljona pridružio se početkom maja 1941. grupi pukovnika Dragoljuba Mihailovića u selu Zaovine na padinama Zlatibora. Pukovnik Mihailović je odmah imenovao Paloševića za svog zamenika i on je tu dužnost obavljao sve do dolaska Dragiše Vasića na Ravnu Goru. Važio je za jednog od najvatrenijh protivnika komunista i Narodnooslobodilačke vojske Jugoslavije. Poginuo je 1945. u borbi sa jedinicama Narodnooslobodilačke vojske Jugoslavije.

${ }^{18}$ Opširnije o kretanju ove grupe videti: B. Dimitrijević, K. Nikolić, Đeneral Mihailović. Biografija, Beograd 2004; R. Martinović, Od Ravne gore do Vrhovnog štaba, Beograd 1982. 
Drugi četnički bataljon nalazio se od početka rata u stalnom povlačenju. Nema dostupnih podataka o borbama koje je, eventualno, vodio sa Nemcima. Bataljon se, zajedno sa Štabom Četničke komande, predao nemačkim snagama u Sarajevu 18. aprila 1941.

O borbenim dejstvima Trećeg četničkog bataljona tokom Aprilskog rata 1941. sačuvan je mali broj izvornih podataka. Ovaj bataljon je 8. aprila dobio naređenje da brani ulaz u Kačaničku klisuru sa jednom četom Sedmog četničkog bataljona. Praktično, Štab Četničke komande je kao pojačanje Trećem četničkom bataljonu uputio onu istu četu koju je izuzeo iz njegovog sastava radi formiranja Sedmog četničkog bataljona. Razbijeni ostaci ovog bataljona su se ubrzo posle prodora snažnih nemačkih oklopno- mehanizovanih jedinica kroz Kačaničku klisuru, 12. aprila predali ne uspevši da se konsoliduju i nastave efikasan otpor nemačkim snagama koje su munjevito napredovale tim pravcem.

Četvrti četnički bataljon se u noći 4/5. aprila prebacio iz matičnog garnizona u Karlovcu u Bjelovar. Zbog snažnog prodora preko reke Drave kod Đekenješa i reke Mure kod sela Letenja od strane jakih jedinica 46. korpusa nemačke Druge armije, Štab Četvrte armije kome je u međuvremenu prepotčinjen ovaj bataljon naredio je komandantu ovog bataljona da odmah premesti bataljon u selo Đurđevac, pripremi ga za diverzantske akcije i čeka dalja naređenja. Komandantu Četvrte armije je bilo poznato da u ovom bataljonu postoji izrazita aktivnost proustaških snaga pa ga zato nije upotrebio za gušenje ustaške pobune koja je izbila u Bjelovaru 9. aprila u jedinicama 108. pešadijskog i 40. dopunskog puka. Već 10. aprila, ovaj bataljon, zahvaćen ustaškom propagandom i defetizmom, predao se Nemcima. ${ }^{19}$ Peti četnički bataljon se sve do 8 . aprila nalazio u Nišu gde je obezbeđivao Štab Pete armije. Stab Pete armije je posle pada Pirota 8. aprila uputio na Špajske položaje združeni odred u čijem sastavu su, osim Petog četničkog bataljona, bili i motorizovani divizion Druge konjičke divizije, armijski pionirski bataljon i neke manje artiljerijske jedinice iz sastava armijskog artiljerijskog puka. Ovaj bataljon se pod borbom povlačio do rejona Kraljeva, gde su ga 14. aprila zarobili Nemci. Inače, zbog preopterećenosti železničkog saobraćaja, a potom i iznenadnog nemačkog napada na Jugoslaviju naređenje ministra vojske i mornarice o prebacivanju ovog bataljona u širi rejon Kraljeva nije izvršeno, pa je on prepotčinjen Štabu Pete armije. ${ }^{20}$ Tako je propala i ideja o prikupljanju četničkih jedinica na prostoru Kraljeva kako bi posle stvaranja jače grupe četničkih snaga otpočela veća gerilska dejstva.

Najviše podataka sačuvano je o borbenim dejstvima Šestog četničkog bataljona. Ovaj bataljon je 4. aprila prebačen iz mirnodopskog sedišta u Mostaru u Mladenovac, odakle je peške upućen Azanju gde se nalazio Štab Šeste armije kome je bataljon prepotčinjen. Transport železnicom je obavljen sa danom zakašnjenja zbog velikog prometa i ogromnog priliva izbeglica iz Beograda. Šesti čet-

${ }^{19}$ AVII, P 17, K 8a, reg. br. 2/39.

${ }^{20} \mathrm{~V}$. Terzić, $n$. $d$., II tom, 331. 
nički bataljon je 9. aprila popodne kamionima prebačen u Topolu, zajedno sa Štabom Šeste armije. Transport se teško odvijao zbog zakrčenosti puta velikim brojem komorskih kola. Rano ujutro 10. aprila bataljon je autobusima prebačen u selo Čumić na putu Topola-Kragujevac. Tog dana komandant bataljona major Ljubodrag Tadić dobio je naređenje da pokrene bataljon u pravcu Kragujevca i da tamo uspostavi red i mir pošto su se građani posle povlačenja vojske iz Kragujevca domogli oružja i počeli da prave pometnju, a da po uspostavljanju vojne vlasti u gradu krene ka selu Sabanta, pod svoju komandu stavi pešadijske delove koji se povlače tim pravcem i organizuje odbranu Kragujevca na tom pravcu. Bataljon je krenuo na izvršenje zadatka, ali je posle petnaestak minuta marševanja susreo jedan konjički eskadron koji je bezglavo bežao pred kolonom nemačkih tenkova. Bataljon je počeo da se povlači većim delom severno od puta i manjim delom (vod za vezu i deo Štabnog voda) južno od puta. U zaštitnici je ostao deo Prve čete pod komandom komandira ove čete, kapetana II klase Branka Životića. ${ }^{21}$ Zaštitnica je pružila relativno jak otpor, uspevši da uništi tri tenka. U ovoj borbi poginuo je kapetan Životić koji je sam uništio jedan tenk. Od tog trenutka bataljon se nalazio u stalnom povlačenju. Snabdevanje je do 10. aprila bilo besprekorno, a kasnije ga nije ni bilo. Bataljon se predao Nemcima u Gornjem Milanovcu 15. aprila.

Posle borbe kod sela Čumića bataljon je napustio komandir Druge čete kapetan I klase Dragomir Marković, koji se odmah po dolasku u Mostar stavio na raspolaganje Hrvatskom vojnom zapovjedništvu Mostara. Isto je učinio i komandir voda za vezu ovog bataljona poručnik Ivan Petružela, pošto su ga Nemci oslobodili iz zarobljeništva nekoliko dana posle zarobljavanja. ${ }^{22}$ Inače, ovaj bataljon je korišćen u martu 1941. za gušenje ustaške pobune u aktiviranim jedinicama 32. pešadijskog puka u Imotskom i Ljubuškom. Pošto nije imao poverenje u oficire hrvatske nacionalnosti, komandant bataljona major Tadić je na ovakve zadatke uz komandire jedinica Hrvate slao oficire srpske nacionalnosti. Ove akcije su bile demonstrativne prirode, sa ciljem pokazivanja snage vojske i primoravanja obveznika hrvatske nacionalnosti na odazivanje vojnim pozivima. Prilikom izvršenja ovih zadataka nije zabeležena primena sile. ${ }^{23}$ Prema izjavi poručnika Petružele, koju je dao vlastima NDH posle stupanja u domobranstvo, bataljon je u Šumadiji bio izuzetno dobro primljen od strane lokalnog stanovništva koje je sa neskrivenim zadovoljstvom i simpatijama pozdravljalo njegove pripadnike nudeći im hranu i piće, obasipajući ih poštovanjem i gostoprimstvom na svakom koraku. ${ }^{24}$

${ }^{21}$ Kapetan II klase Branko Životić rođen je 1912. u selu Kumodraž kod Beograda. Završio je LIX klasu Vojne akademije 1933. godine. Do 1940. bio je komandir voda u školi za rezervne pešadijske oficire u Sarajevu kad je postavljen na dužnost komandira prve čete Šestog četničkog bataljona. Jedan je od devet pripadnika jurišnih (četničkih) jedinica koji su na manevrima u okolini Beograda 9. septembra 1940. demonstrirali rad diverzantske grupe u neprijateljskoj pozadini. Posebno se istakao prilikom gušenja ustaške pobune u Imotskom u martu 1941. Poginuo je 12. aprila 1941. u selu Čumiću u borbi sa nemačkim oklopnim jedinicama.

${ }^{22}$ AVII, P 17, K 66, reg. br. 466/9-2 .

${ }^{23}$ AVII, P 17, K 66, reg. br. 467/9-1.

${ }^{24}$ AVII, P 17, K 66, reg. br. 466/9-2 . 
Sedmi četnički bataljon je, bez čete koju je uputio u sastav Trećeg četničkog bataljona, zajedno sa Protivavionskim divizionom Štaba Vrhovne komande tokom 12. i 13. aprila 1941. dejstvovao na frontu Prve armije u širem rejonu Zvornika protiv nemačkih oklopno-mehanizovanih jedinica pri čemu je imao prilično uspeha. Pripadnici ovih jedinica u tim borbama su uspeli da unište nekoliko nemačkih tenkova i kamiona. Posle tih borbi Sedmi četnički bataljon se pod borbom povukao do Sarajeva gde se zajedno sa Drugim četničkim bataljonom i Štabom Četničke komande 18. aprila predao Nemcima. ${ }^{25}$ Kada je u pitanju Sedmi četnički bataljon, mora se imati u vidu činjenica da se radilo o bataljonu koji se nalazio još uvek u procesu formiranja, da je bio slabo popunjen i da je prethodno, 8. aprila, vratio četu koja mu je bila pridodata iz sastava Trećeg četničkog bataljona tako da je bio sveden samo na jednu četu uz Štab, Štabni vod, vod za vezu i pozadinske delove. S obzirom na takvo stanje, jedinica je u datim okolnostima maksimalno bila napregnuta u borbama oko Zvornika gde je postigla značajan uspeh.

Postojeći izvori pružaju veoma mali broj podataka o gubicima koje su pretrpele četničke jedinice u borbi sa nemačkim snagama. Pouzdano se može utvrditi da su iz Šestog četničkog bataljona u borbi sa prethodnicom nemačke 11. oklopne divizije kod sela Čumića poginuli jedan oficir i dva vojnika, a da je tom prilikom ranjeno i nekoliko podoficira i vojnika. ${ }^{26}$ Postoji više kontroverznih podataka o tome kolike i kakve je gubitke pretrpeo Prvi četnički bataljon u borbi sa nemačkim snagama. Pojedini autori netačno navode da je „ovaj bataljon izginuo do poslednjeg čoveka“. ${ }^{27}$ Činjenica je da je ovaj bataljon prilikom odbrane bijeljinskog aerodroma imao velike gubitke, ali se ukupan broj i vrsta gubitaka ne mogu precizno utvrditi na osnovu podataka koje pružaju dostupni izvori. Sem toga, zna se da je i Sedmi četnički bataljon pretrpeo osetne gubitke u borbi sa delovima nemačke 16. motorizovane divizije u rejonu Zvornika ali nema sačuvanih podataka o broju i vrsti gubitaka ovog bataljona. ${ }^{28} \mathrm{O}$ eventualnim gubicima ostalih četničkih bataljona nema raspoloživih podataka. Važno je napomenuti da su ostatke četničkih jedinica, sem malog broja oficira, podoficira i vojnika koji su izbegli zarobljavanje, zarobile nemačke jedinice.

Zarobljavanjem Štaba Četničke komande i njenih preostalih jedinica završeno je učešće četničkih jedinica Vojske Kraljevine Jugoslavije u kratkotrajnom Aprilskom ratu 1941. Ove jedinice su mestimično pružile snažan otpor u okvirima svojih borbenih mogućnosti. Četničke jedinice su bile borbeno najsposobniji deo vojske koja je sa ogromnim slabostima ušla u rat sa, i u kvalitativnom i u kvantitativnom pogledu, neuporedivo spremnijim protivnikom. Kratkotrajan otpor glavnine jedinica Vojske Kraljevine Jugoslavije nije omogućio četničkim

\footnotetext{
${ }^{25} \mathrm{~V}$. Terzić, n. d. , II tom, 411.

${ }^{26}$ AVII, P 17, K 66, reg. br . 466 / 9-2 .

${ }^{27} \mathrm{~B}$. Bogdanović, n. d., 118.

${ }^{28} \mathrm{~V}$. Terzić, $n$. d., II tom, 410, 434.
} 
jedinicama da na odgovarajući način iskažu svoje borbene kvalitete. Sem toga, potpuno disperzivno komandovanje ovim snagama nije dozvolilo Štabu Četničke komande da na efikasan način koordinira dejstva tih jedinica i osigura duži gerilski otpor na zaposednutoj teritoriji Kraljevine Jugoslavije.

Aleksandar Životić

\section{THE CHETNIK UNITS OF THE YUGOSLAV ARMY IN APRIL WAR 1941}

\section{Summary}

On hte basis of the experiences of the Serbian Army form the Balkan and First Wolrd War, The Yugoslav Generalstaff in 1940 decided to create special „Chetnik“ units for the guerrila warfare. Knowing its Army inadequacy to match techincally superrior opponents, Yugoslav highest military cirlcles, decided to choose the guerrilla patterns for the resistance. They also counted on the mountainious terrain as ideal for such kind of resistance. Seven independent Chetnik (assault) batallions were formed and specially trained fot the guerrilla warfare. During the short April War in 1941, those Chetnik units operated separated for the main body of the Army, and occasionally performed well in combat. However, they faced the equall faith of the rest of the Yugoslav forces which capitulated on the 17th of April 1941. They did not continued with the planned resistance, after the defeatof the Yugoslav Army. Several of members of the Chetnik army units joined the resistance Yugoslav Army in Fatherland lead by the General Draža Mihailović. 